\title{
Kajian Ekonomi Rencana PLTMH di Desa Panji
}

\author{
Richard Antony Suatan ${ }^{1}$, Ida Ayu Dwi Giriantari ${ }^{2}$, I Wayan Sukerayasa ${ }^{3}$
}

[Submission 29-11-2020:, Accepted:30-12-2020]

\begin{abstract}
The micro hydro power plant (PLTMH) in Banjar Dinas Mekar Sari, was built independently by community groups in 1980. With the use of traditional technology, the efficiency of PLTMH is low, so it is necessary to re-plan for PLTMH Banjar Dinas Mekar Sari so that it can operate optimally. One of the most important factors in planning is financial / economic factors. This factor will be used to assess a plan whether it is feasible to build or not. The parameters used in determining economic factors are Net Present Value (NPV, Internal Rate of Return (IRR), Benefit to Cost Ratio (BCR), Life Cycle Cost (LCC), and Break Even Point (BEP). Economic feasibility analysis has been carried out. for planning PLTMH Banjar Dinas Mekar Sari obtained, BCR of 1.05 and 0.79 and NPV values of IDR 3,320,076,318 and IDR 2,520,526,334 are positive, and the IRR values of $13 \%$ and $11 \%$ exceed the Expected Annual Rate of Return. Indonesia, which is $11.4 \%$. As well as the amount of BEP units that must be sold to reach the cash flow point is Rp. 0 of 3,783,633.30 $\mathrm{kWh}$, and the amount of the payback period for this project is 5 years 3 months. So it can be seen from the existing economic parameters. hence the design of PLTMH in Banjar Dinas Mekar Sari is feasible in terms of economic parameters.
\end{abstract}

Keywords--- PLTMH, MycroHydro, Renewable Energy, Economic Feasability.

Intisari- Pembangkit listrik tenaga mikrohidro (PLTMH) di Banjar Dinas Mekar Sari, telah dibangun oleh kelompok masyarakat secara swadaya pada tahun 1980. Dengan penggunaan teknologi yang tradisional mengakibatkan efisiensi PLTMH rendah, sehingga perlu dilakukan perencanaan ulang bagi PLTMH Banjar Dinas Mekar Sari agar dapat beroperasi lebih optimal. Salah satu faktor yang sangat penting dalam perencanaan yaitu faktor finansial/ekonomi. Faktor ini akan digunakan untuk menilai suatu perencanaan apakah layak dibangun atau tidak. Parameter yang digunakan dalam menentukan faktor ekonomi yaitu Net Present Value (NPV, Internal Rate of Return (IRR), Benefit to Cost Ratio (BCR), Life Cycle Cost (LCC), dan Break Even Point (BEP). Telah dilakukan analisis kelayakan ekonomi untuk perencanaan PLTMH Banjar Dinas Mekar Sari diperoleh, BCR sebesar 1,05 dan 0.79 serta nilai $N P V$ sebesar Rp3.320.076.318 dan Rp2.520.526.334 bernilai positif, dan besarnya nilai IRR $13 \%$ dan $11 \%$ melebihi tingkat Expected Annual Rate of Return Indonesia yang sebesar 11,4\%. Serta besarnya $B E P$ unit yang harus dijual untuk mencapai titik cash flow bernilai Rp.0 sebesar $3.783 .633 .30 \mathrm{kWh}$, dan besarnya payback period pada proyek ini yaitu 5 tahun 3 bulan. Jadi dilihat dari parameter ekonomi yang ada maka perancangan PLTMH di Banjar Dinas Mekar Sari layak dari segi parameter

\footnotetext{
${ }^{1}$ Mahasiswa, Universitas Udayana, Perumahan Padang Galeria 1 no. 4 Denpasar, 80117; (telp: 081338931121; e-mail: suatanrichard@gmail.com)

2,3 Dosen, Program Studi Teknik Elektro Fakultas Teknik Universitas Udayana, Jln. Jalan Kampus Bukit Jimbaran 80361 INDONESIA (telp: 0361-703315; fax: 0361-4321; e-mail: 2dayu.giriantari@unud.ac.id,'sukerayasa@unud.ac.id)
}

Richard Antony Suatan : Kajian Ekonomi Untuk Perencanaan... ekonomi.

Kata Kunci- PLTMH, Mikrohidro, Energi Terbarukan, Kelayakan Ekonomi.

\section{PENDAHULUAN}

Indonesia memiliki sumber daya alam yang melimpah, salah satunya adalah aliran sungai yang dapat dimanfaatkan sebagai pembangkit tenaga listrik. Potensi energi mini-micro hydro di Indonesia adalah sebesar 19.385 MW dan 30 MW diantaranya terdapat di Bali, sedangkan pemanfaatannya hanya 197,4 MW, sekitar 1\% dari potensi [1].

Pembangkit listrik tenaga mikrohidro (PLTMH) adalah salah satu pembangkit listrik yang dapat dikembangkan pada daerah aliran sungai. Pembangkit listrik tenaga air yang menghasilkan daya dibawah $200 \mathrm{~kW}$ digolongkan kedalam pembangkit listrik tenaga mikrohidro. PLTMH memiliki keunggulan karena dapat diaplikasikan pada aliran dengan debit air yang tidak terlalu besar dan PLTMH juga tidak menggunakan komponen kelistrikan yang rumit, serta dengan ukuran yang lebih kecil, proses instalasi lebih mudah dilakukan, terutama dalam perencanaan pembangunan pada sungai yang terletak di daerah hutan dan desa terpencil.

Pembangkit Listrik Tenaga Mikro Hidro dapat mengurangi penggunaan pembangkit tenaga thermal yang tidak ramah lingkungan. Salah satu potensi PLTMH berada di sungai Muara yang terletak di Banjar Dinas Mekar Sari, Desa Panji, Kecamatan Sukasada, Kabupaten Buleleng. Sebelumnya sudah pernah di bangun PLTMH kincir di lokasi ini oleh sekelompok masyarakat secara swadaya dengan menggunakan material yang sangat sederhana dan tradisional, yaitu menggunakan kayu dan bambu sebagai penopangnya. Karena kemampuan teknis masyarakat yang kurang, mengakibatkan efisiensi sistem sangat rendah dan keadaannya sekarang terbengkalai.

Untuk itu dalam penelitian ini dirancang PLTMH di Banjar Dinas Mekarsari, Desa Panji, Kecamatan Sukasada, Kabupaten Buleleng. Fokus Penelitian ini ditinjau dari segi Ekonomi Proyek dengan metode internal rate of return, benefit to cost ratio, net present value, cash flow, Life Cycle Cost, dan Break Even Point, untuk mengetahui apakah proyek ini layak secara ekonomi atau tidak.

\section{Komponen KAJIAn EKONOMI PEMBANGKIT ListRIK MIKROHIDRO}

\section{A. Pembangkit Listrik Tenaga Mikrohidro (PLTMH)}

Sumber energi baru terbarukan adalah sumber energi ramah lingkungan yang tidak mencemari lingkungan dan tidak memberikan kontribusi terhadap perubahan iklim dan pemanasan global, karena energi yang didapatkan berasal dari proses alam yang berkelanjutan, seperti sinar matahari, angin, air, biofuel, dan geothermal. Ini menegaskan bahwa sumber energi telah tersedia, tidak merugikan lingkungan, dan

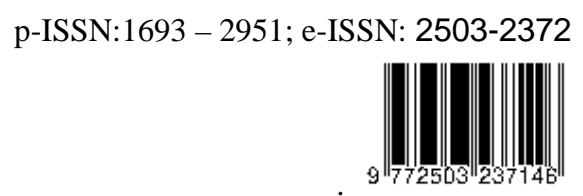


menjadi alasan utama mengapa Energi Baru Terbarukan (EBT) sangat terkait dengan masalah lingkungan dan ekologi [2].

Salah satu pembangkit listrik EBT adalah pembangkit listrik tenaga mikrohidro, yaitu pembangkit listrik tenaga air skala kecil dengan kapasitas antara 5kW - 1MW per unit [3].

Energi potensial air dapat diubah menjadi energi listrik melalui beberapa komponen PLTMH. Untuk mengalihkan aliran air, diperlukan sebuah bendung (weir) sebagai penghalang, kemudian disalurkan menuju bangunan penyadap (intake) dan diarahkan oleh saluran pembawa (channel) yang berada di sepanjang sisi bukit. Kemudian terdapat saluran pelimpah (spillways) yang berfungsi untuk melindungi dari kerusakan akibat aliran air berlebih. Aliran air yang telah diperlambat selanjutnya ditampung pada bak penenang, yang kemudian air menuju ke pipa pesat (penstock) untuk mengalirkan air menuju turbin yang akan memutar generator pada power house. Setelah melalui power house air kemudian di buang melalui pipa pembuangan [4].

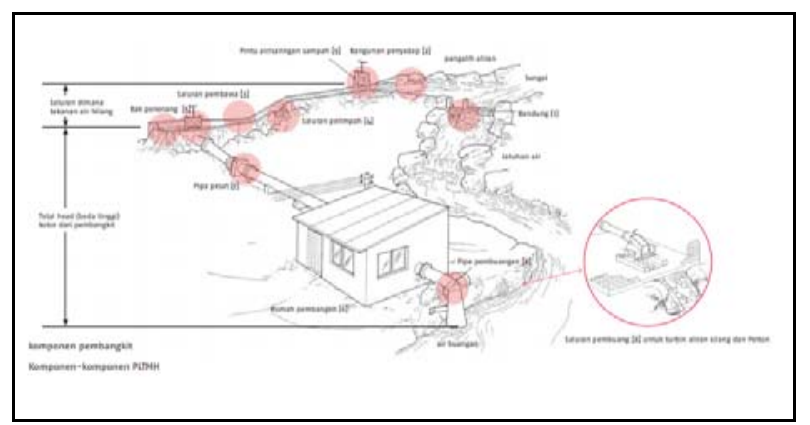

Gambar 1. Skema dan Komponen PLTMH

Energi air dimanfaatkan dan diubah menjadi energi listrik dengan pembangkir listrik tenaga air tanpa meninggalkan emisi gas rumah kaca seperti yang dihasilkan oleh pembangkit listrik yang menggunakan energi fosil [5].

Parameter yang digunakan dalam energi air yaitu debit air. Debit air merupakan laju air yang mengalir pada suatu bidang. Laju air dipengaruhi oleh besarnya hambatan yang diterima air, diantaranya belokan pada aliran air.

Besarnya debit air sungai di desa Panji sebagai berikut [6].

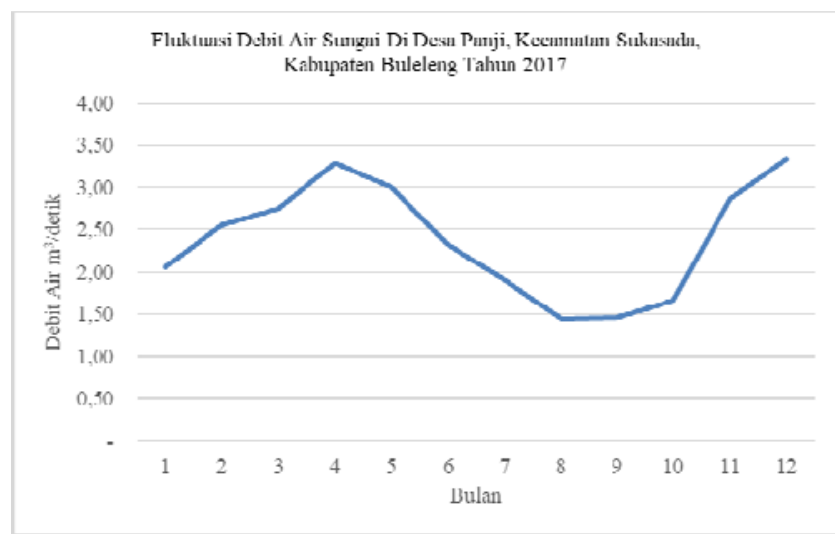

Gambar 2. Fluktuasi Debit Air Sungai di Desa Panji

Dari gambar di atas dapat dilihat fluktuasi debit air dalam satu tahun. Dan dari fluktuasi rata-rata per bulan di atas, dapat dicari rata-rata besarnya debit air selama satu tahun yaitu $2,39 \mathrm{~m}^{3} /$ detik.

Selain debit air, tinggi jatuh air (head) merupakan salah satu faktor yang mempengaruhi energi air dalam menghasilkan energi listrik. Tinggi jatuh air dipengaruhi oleh beberapa faktor diantaranya faktor belokan yang ada dan juga gesekan yang terjadi antara air dengan permukaan bidang pengalir air. Tinggi jatuh air sungai yang optimal di Banjar Dinas Mekar Sari setelah di kurangi besarnya rugi rugi penstock yaitu $16 \mathrm{~m}$ [7].

\section{B. Kelayakan Ekonomi/Finansial}

Kelayakan ekonomi finansial merupakan salah satu faktor penentu dalam keberlanjutan suatu proyek. Dan kegunaan parameter kelayakan secara ekonomi / finansial yaitu untuk memperhitungkan besarnya keuntungan atau kerugian yang akan di terima pada suatu proyek [8].

Parameter pengukuran kelayakan ekonomi yang digunakan diantaranya.

\section{Life Cycle Cost}

Life cycle cost merupakan suatu konsep pemodelan perhitungan biaya dari tahap permulaan sampai tahap pembongkaran aset serta perhitungan total biaya sepanjang umur ekonomis aset [9].

Biaya yang termasuk dalam perhitungan LCC yaitu initial cost, energy cost, operational and maintenance cost, dan disposal cost.

Rumus perhitungan LCC sebagai berikut.

$$
L C C=C+C e+C o m+C d
$$

Keterangan :

LCC = Life Cycle Cost

$\mathrm{C}=$ Initial Cost

$\mathrm{Ce}=$ Biaya Energi (bahan bakar)

Com = Biaya operasional dan maintenance

$\mathrm{Cd}=$ Biaya pembuangan aset (disposal)

\section{Break Even Point}

Break even point merupakan suatu keadaan modal yang dikeluatkan sama dengan besarnya pendapatan, sehingga break even point dapat dikatakan sebagai titik balik modal suatu proyek [10].

BEP menggunakan satuan unit, sehingga yang dihitung dari parameter BEP adalah banyaknya unit yang harus dijual untuk mencapai titik balik ekonomis proyek/aset.

Rumus BEP yaitu.

$$
\text { BEP unit }=\frac{\text { Inttalcast }}{(\text { harga per wnt } t-\text { B taya per untt) }}
$$

Keterangan :

BEP unit $=$ Break Even Point unit

Initial Cost $=$ Biaya Investasi

Harga per unit $=$ Tarif lisrtrik per kWh

Biaya variable per unit = biaya sepanjang umur ekonomis PLTMH

\section{Benefit Cost Ratio (BCR)}

Merupakan perbandingan antara keuntungan yang diperoleh dari investasi suatu proyek. Faktor penentu BCR yaitu bila BCR > 1, maka proyek dikatakan layak, karena keuntungan melebihi modal investasi

$$
B C R=\frac{N P F}{\text { Initial cost }}
$$


Keterangan :

BCR $=$ Benefit Cost Ratio

NPV $=$ Net Present Value

Investment Cost $=$ Besarnya Biaya Investasi

4. Net Present Value (NPV)

NPV merupakan jumlah dari keseluruhan benefit setelah diubah ke nilai saat ini (PV) dari nilai FV. Maka parameter NPV harus memiliki nilai positif atau lebih dari 0 untuk suatu proyek dapat dikatakan layak.

$$
N P V=\sum_{n=0}^{x} \frac{C F_{n}}{\left(1+n^{N}\right.}
$$

Keterangan :

NPV $=$ Net Present Value

$\mathrm{CF}=$ arus kas

$\mathrm{i}=$ Interest rate (tingkat suku bunga)

$\mathrm{n}$ = jangka waktu proyek

5. Internal Rate of Return (IRR)

IRR merupakan perhitungan parameter untuk mencari besarnya potensi balik moda dari suatu investasi. IRR di representasikan dalam persentase (\%).

$$
I R R=i 1+\frac{N P V(+)}{(N P V P(+)-N P P(-)} \approx(i 2-i 1)
$$

Keterangan :

IRR = Internal Rate of Return.

NPV $=$ Net Present Value.

i1 = tingkat suku bunga yang memberikan nilai NPV positif.

i2 = tingkat suku bunga yang memberikan nilai NPV negatif.

Untuk menentukan kelayakan parameter IRR, diperlukan besarnya Required Rate of Return (RRR). Dimana besarnya RRR ditentukan oleh besanya Expected Annual Rate of Return Indonesia yang sebesar 11,4\% [11].

\section{Arus Kas (Cash Flow)}

Arus kas merupakan suatu parameter untuk mencatat pendapatan dan pengeluaran dalam suatu investasi dalam periode waktu umur ekonomis suatu proyek atau aset.

\section{Payback period (PP)}

PP merupakan suatu parameter pengukuran jangka waktu yang diperlukan suatu aset untuk mencapai cash flow bernilai 0 , pendapatan sudah mampu menutupi besarnya biaya investasi (initial cost). [12]

Keterangan :

$$
P P=n+\frac{a-b}{c-b} \times 1 \text { tahtan }
$$

$\mathrm{PP}=$ Payback period

$\mathrm{n}$ = tahun terakhir jumlah arus kas belum mampu menutupi modal investasi

$\mathrm{a}=$ initial cost

$\mathrm{b}=$ jumlah arus kas hingga tahun ke $-\mathrm{n}$

$\mathrm{c}=$ jumlah arus kas hingga tahun $\mathrm{ke}-\mathrm{n}+1$

\section{Metodologi Penelitian}

Langkah langkah yang dilakukan dalam melakukan analisa ekonomi yaitu, pencarian spesifikasi dan komponen yang Richard Antony Suatan : Kajian Ekonomi Untuk Perencanaan... diperlukan untuk perhitungan investasi yang diperlukan dalam perencanaan PLTMH. Pengumpulan data dilakukan dengan metode pengumpulan data primer dan data sekunder. Data primer berupa observasi di lokasi penelitian untuk melihat keadaan PLTMH terkini.

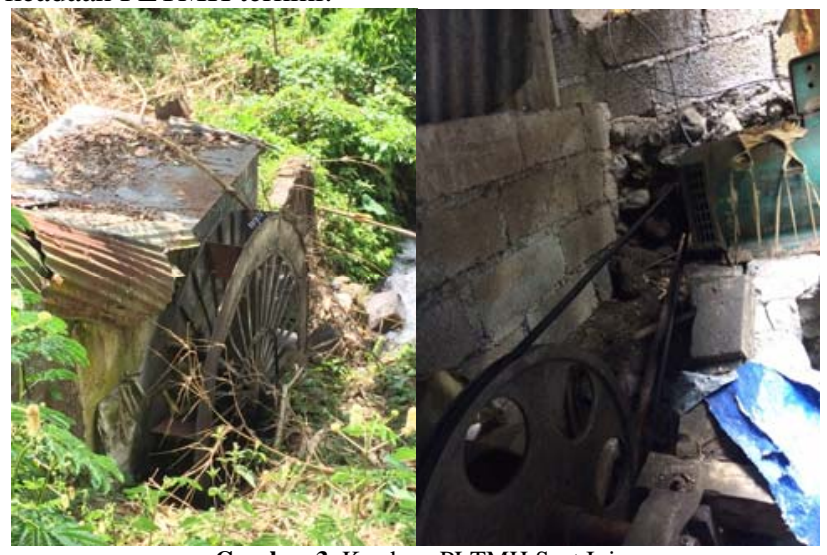

Gambar 3. Keadaan PLTMH Saat Ini

Untuk data sekunder yang dicari berupa spesifikasi dan komponen dari PLTMH, mulai dari pipa pesat (penstock), Turbin, dan kelistrikan. Selain itu, dicari juga besarnya pembangkitan PLTMH. Setelah diperoleh data primer dan sekunder kemudian dilanjutkan dengan analisis ekonomi dari perhitungan parameter Life Cycle Cost, cash flow, Net Present Value, Internal Rate of Return, Payback period, dan Break Even Point. Setelah diperoleh besarnya parameter untuk analisis ekonomi, kemudian ditentukan kelayakan dari perencanaan PLTMH.

\section{HASIL DAN PEMBAHASAN}

Setelah dilakukan observasi, PLTMH Banjar Dinas Mekar Sari sudah dibangun sejak tahun 1980 dengan investasi Rp.10.000.000. Dengan pembangkitan saat ini mengalami penurunan efisiensi dari yang awalnya mampu membangkitkan hingga $10 \mathrm{~kW}$, saat ini hanya mampu membangkitkan 200W saja dikarenakan kurangnya pemeliharan pada PLTMH.

Untuk itu perlu dilakukan perencanaan ulang pada PLTMH Banjar Dinas Mekar Sari. Perencanaan ulang PLTMH dengan menggunakan asumsi modal secara swadaya kelompok masyarakat yang berjumlah $22 \mathrm{KK}$. Untuk pemilihan komponen dengan mengambil data perhitungan yang telah ada [7], [13], [14]. Setelah dilakukan perhitungan, maka di peroleh spesifikasi penstock, turbin, dan kelistrikan hasil redesign PLTMH yang optimal dengan debit air dan head pada sungai yang ada di Banjar Dinas Mekar Sari sebagai berikut.

TABEL I

SPESIFIKASI PENSTOCK PLTMH BANJAR DINAS MEKAR SARI

\begin{tabular}{|c|c|c|}
\hline No. & Uraian Perancangan & Hasil Perancangan \\
\hline 1 & Bahan Penstock & Mild Steel Galvanized \\
\hline 2 & Panjang Penstock & $54 \mathrm{~m}$ \\
\hline 3 & Diameter Penstock & $0,8272 \mathrm{~m}$ \\
\hline 4 & Tebal Penstock & $0,0050 \mathrm{~m}$ \\
\hline 5 & Jumlah belokan & 2 belokan \\
\hline
\end{tabular}

p-ISSN:1693 - 2951; e-ISSN: 2503-2372

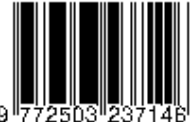




\begin{tabular}{|c|c|c|}
\hline 6 & Sudut belokan pertama & $10^{\circ}$ \\
\hline 7 & Sudut belokan kedua & $60^{\circ}$ \\
\hline 8 & Jumlah katup & 2 katup \\
\hline 9 & Gate Valve & 1 katup \\
\hline 10 & Butterfly Valve & 1 katup \\
\hline 11 & Jumlah Anchor Block & 3 buah \\
\hline 12 & Jumlah Slide Block & 11 buah \\
\hline
\end{tabular}

TABEL II

SPESIFIKASI TURBIN PLTMH BANJAR DINAS MEKAR SARI

\begin{tabular}{|c|c|c|}
\hline No. & Spesifikasi & Ukuran \\
\hline 1 & Daya Turbin & $185 \mathrm{~kW}$ \\
\hline 2 & Putaran Turbin & $298 \mathrm{rpm}$ \\
\hline 3 & Tinggi Jatuh Air & $16 \mathrm{~m}$ \\
\hline 4 & Debit Aliran & $1,32 \mathrm{~m}^{3} /$ detik \\
\hline 5 & Torsi Turbin & $5962,46 \mathrm{Nm}$ \\
\hline 6 & Diameter Luar & $54 \mathrm{~cm}$ \\
& Runner & $19 \mathrm{buah}$ \\
\hline 7 & Jumlah Sudu & $50 \mathrm{~cm}$ \\
\hline 8 & Panjang Runner & \\
\hline
\end{tabular}

Sumber: [13]

Kelistrikan dari PLTMH dilakukan dengan memperhatikan perkembangan teknologi sehingga beberapa komponen yang digunakan dalam kelistrikan PLTMH dapat membantu mengoptimalkan kinerja PLTMH. Besarnya energi yang dapat dihasilkan dari generator dilihat dari potensi debit air yaitu $176 \mathrm{kVa}$, dengan asumsi cos phi sebesar 1 , maka besarnya nilai daya aktif generator yaitu $176 \mathrm{~kW}$. [14].

Dengan memperhatikan besarnya faktor kapasitas, maka besarnya energi yang diterima PLN dikalikan faktor kapasitas sebesar 65\% [15], energi yang akan dijual ke PLN sebesar 114,4 kW. Sehingga dengan asumsi yang digunakan di atas, besarnya energi listrik yang dijual ke PLN dalam satu tahun sebesar.

\section{Energi yang difual ke PLN per tahum $=114,4 k W \times 8760 k$}

\section{$=1.002 .144 \mathrm{kWh} p e r^{-}$tahun}

Saluran kelistrikan PLTMH menggunakan saluran udara dengan menggunakan kabel twsted jenis NFA2X-T 3 x $95+1$ x $70 \mathrm{~mm}^{2}$ sepanjang 69 meter. Line diagram dari perancangan kelistirkan PLTMH ini sendiri dapat dilihat pada gambar berikut.

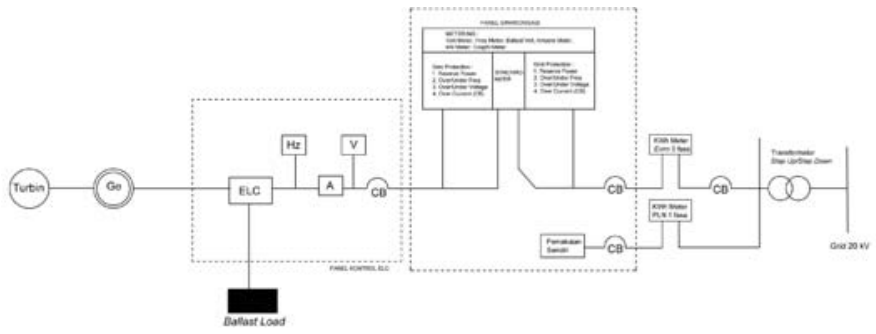

Gambar 4. Line Diagram Sistem PLTMH Banjar Dinas Mekar Sari

Setelah diperoleh komponen penyusun PLTMH maka selanjutnya dihitung besarnya biaya investasi untuk PLTMH Banjar Dinas Mekar Sari seperti pada tabel berikut.

TABEL III

BIAYA INVESTASI PLTMH BANJAR DINAS MEKAR SARI

\begin{tabular}{|l|lr|}
\hline \multicolumn{3}{|c|}{ Biaya Investasi } \\
\hline Jenis Pekerjaan & & \multicolumn{1}{|c|}{ Biaya } \\
\hline Pekerjaan Sipil & $\mathrm{Rp}$ & 1.444 .675 .000 \\
\hline Pekerjaan mekanikal dan elektrikal & $\mathrm{Rp}$ & 1.441 .092 .270 \\
\hline total & Rp & $\mathbf{2 . 8 8 5 . 7 6 7 . 2 7 0}$ \\
\hline ppn $10 \%$ & $\mathrm{Rp}$ & 288.576 .727 \\
\hline Grand Total & Rp & $\mathbf{3 . 1 7 4 . 3 4 4 . 0 0 0}$ \\
\hline
\end{tabular}

Sumber: [16]

Setelah didapatkan besarnya nilai investasi selanjutnya dilakukan perhitungan parameter yang mempengaruhi kelayakan ekonomi/finansial.

\section{A. Life Cycle Cost}

Life cycle cost merupakan besarnya biaya yang harus di keluarkan sepanjang umur ekonomis PLTMH. Biaya yang dikeluarkan merupakan variable cost yang terdiri dari kumpulan biaya, diantaranya biaya operational and maintenance, biaya penyusutan dan biaya penggunaan air permukaan.

1. Biaya Operational And Maintenance (O\&M)

Besarnya biaya $O \& M$ yaitu sebesar $2 \%$ dari initial cost [9], sehingga didapatkan besarnya biaya $O \& M$ tahunan yaitu :

\section{Biaya O\&M = Initial Cost $x 2 \%$ \\ Biaya O\&M $=$ Rp3.174.344.000 $\times 2 \%$ \\ Biaya $0 \& M=R p 63.486 .880$}

Setelah didapatkan besarnya biaya operasional tahunan, maka dicari besarnya biaya $O \& M$ sepanjang umur ekonomis PLTMH. Besarnya biaya O\&M dipengaruhi oleh inflation rate yang telah diasumsikan sebesar 6\%. Dan kemudian dicari besarnya present value dari biaya $O \& M$ ini dengan tingkat diskonto sebesar $10 \%$ dan $12 \%$ [17].

Pada tabel IV diketahui bahwa besarnya biaya O\&M selama 30 tahun sebesar Rp.1.064.752.479 dengan tingkat diskonto 10\%, dan Rp.855.267.936 dengan tingkat diskonto $12 \%$. 
2. Biaya Penyusutan

Biaya penyusutan merupakan suatu parameter untuk mengalokasikan biaya. Penyusutan (depreciation) adalah suatu proses untuk mengalokasikan biaya aktiva berwujud ke beban dengan cara yang sistematis dan rasional sepanjang umur ekonomis yang diharapkan mendapat manfaat dari penggunaan aktiva tersebut. Faktor-faktor yang mempengaruhi biaya penyusutan adalah harga perolehan (initial cost), nilai residu, dan umur ekonomis penggunaan aset. Perhitungan besarnya biaya penyusutan sebagai berikut.

TABEL IV

BIAYA O\&M PLTMH BANJAR DINAS MEKAR SARI

\begin{tabular}{|c|c|c|c|c|}
\hline \multicolumn{5}{|c|}{ Biaya O\&M } \\
\hline Tahun & Tahun ke- & $\begin{array}{l}\text { Biaya O\&M Dengan } \\
\text { Inflasi } 6 \% / \text { tahun }\end{array}$ & $\begin{array}{c}\text { PV Biaya O\&M } \\
\text { dengan Discount Rate } \\
10 \%\end{array}$ & $\begin{array}{c}\text { PV Biaya O\&M } \\
\text { dengan Discount Rate } \\
12 \%\end{array}$ \\
\hline 2020 & 0 & Rp0 & Rp0 & Rp0 \\
\hline 2021 & 1 & Rp63.486.880 & Rp57.715.345 & Rp56.684.714 \\
\hline 2022 & 2 & Rp67.296.093 & Rp55.616.606 & Rp53.648.033 \\
\hline 2023 & 3 & Rp71.333.858 & Rp53.594.184 & Rp50.774.031 \\
\hline 2024 & 4 & Rp75.613.890 & Rp51.645.304 & Rp48.053.994 \\
\hline 2025 & 5 & Rp80.150.723 & Rp49.767.293 & Rp45.479.673 \\
\hline 2026 & 6 & Rp84.959.767 & Rp47.957.573 & Rp43.043.262 \\
\hline 2027 & 7 & Rp90.057.353 & Rp46.213.662 & Rp40.737.373 \\
\hline 2028 & 8 & Rp95.460.794 & Rp44.533.165 & Rp38.555.014 \\
\hline 2029 & 9 & Rp101.188.441 & Rp42.913.777 & Rp36.489.566 \\
\hline 2030 & 10 & Rp107.259.748 & Rp41.353.276 & Rp34.534.768 \\
\hline 2031 & 11 & Rp113.695.333 & Rp39.849.521 & Rp32.684.691 \\
\hline 2032 & 12 & Rp120.517.053 & Rp38.400.447 & Rp30.933.726 \\
\hline 2033 & 13 & Rp127.748.076 & Rp37.004.067 & Rp29.276.562 \\
\hline 2034 & 14 & Rp135.412.961 & Rp35.658.465 & Rp27.708.175 \\
\hline 2035 & 15 & Rp143.537.738 & Rp34.361.793 & Rp26.223.808 \\
\hline 2036 & 16 & Rp152.150.002 & Rp33.112.274 & Rp24.818.961 \\
\hline 2037 & 17 & Rp161.279.003 & Rp31.908.191 & Rp23.489.374 \\
\hline 2038 & 18 & Rp170.955.743 & Rp30.747.893 & Rp22.231.015 \\
\hline 2039 & 19 & Rp181.213.087 & Rp29.629.788 & Rp21.040.067 \\
\hline 2040 & 20 & Rp192.085.873 & Rp28.552.341 & Rp19.912.921 \\
\hline 2041 & 21 & Rp203.611.025 & Rp27.514.074 & Rp18.846.157 \\
\hline 2042 & 22 & Rp215.827.686 & Rp26.513.562 & Rp17.836.542 \\
\hline 2043 & 23 & Rp228.777.348 & Rp25.549.433 & Rp16.881.013 \\
\hline 2044 & 24 & Rp242.503.988 & Rp24.620.362 & Rp15.976.673 \\
\hline 2045 & 25 & Rp257.054.228 & Rp23.725.077 & Rp15.120.780 \\
\hline 2046 & 26 & Rp272.477.481 & Rp22.862.346 & Rp14.310.738 \\
\hline 2047 & 27 & Rp288.826.130 & Rp22.030.988 & Rp13.544.091 \\
\hline 2048 & 28 & Rp306.155.698 & Rp21.229.862 & Rp12.818.515 \\
\hline 2049 & 29 & Rp324.525.040 & Rp20.457.867 & Rp12.131.809 \\
\hline 2050 & 30 & Rp343.996.542 & Rp19.713.944 & Rp11.481.890 \\
\hline \multicolumn{2}{|c|}{ Total } & Rp5.019.157.581 & Rp1.064.752.479 & Rp855.267.936 \\
\hline
\end{tabular}

$$
\begin{aligned}
& \text { biaya penyusutan }=\frac{\text { initial cost }- \text { nilai residu }}{\text { umn ekononts }} \\
& \text { biaya penyusutan }=\frac{R p 3.174 .344 .000-0}{30}
\end{aligned}
$$

\section{biaya penyesutan $=\operatorname{Rp} 105.811 .467$}

Nilai Residu pada perhitungan berrnilai 0, karena diasumsikan pada akhir umur ekonomis, aset tidak dijual kembali dan tidak juga ditukarakan sehingga besarnya nilai residu ialah 0 . Setelah di dapatkan besarnya biaya penyusutan (depresiasi) maka selanjutnya dicari proyeksi besarnya biaya penyusutan sepanjang umur ekonomis aset dengan besarnya inflasi 6\% per

Richard Antony Suatan : Kajian Ekonomi Untuk Perencanaan... tahun besarnya present value dengan tingkat diskonto $10 \%$ dan $12 \%$.

Besarnya present value biaya penyusutan total yaitu Rp.1.774.587.465 dengan tingkat diskonto $10 \%$ dan Rp.1.425.446.560 dengan tingkat diskonto $12 \%$.

TABEL V

\begin{tabular}{|c|c|c|c|c|}
\hline \multicolumn{5}{|c|}{ Biaya Penyusutan } \\
\hline Tahun & Tahun ke- & $\begin{array}{c}\text { Biaya Penyusutan } \\
\text { dengan Infalasi } \\
6 \% / \text { tahun }\end{array}$ & $\begin{array}{c}\text { PV Biaya Penyusutan } \\
\text { dengan Discount Rate } \\
10 \%\end{array}$ & $\begin{array}{c}\text { PV Biaya Penyusutan } \\
\text { dengan Discount Rate } \\
12 \%\end{array}$ \\
\hline 2020 & 0 & Rp0 & Rp0 & Rp0 \\
\hline 2021 & 1 & Rp105.811.467 & Rp96.192.242 & Rp94.474.524 \\
\hline 2022 & 2 & Rp112.160.155 & Rp92.694.343 & Rp89.413.389 \\
\hline 2023 & 3 & Rp118.889.764 & Rp89.323.639 & Rp84.623.386 \\
\hline 2024 & 4 & Rp126.023.150 & Rp86.075.507 & Rp80.089.990 \\
\hline 2025 & 5 & Rp133.584.539 & Rp82.945.489 & Rp75.799.455 \\
\hline 2026 & 6 & Rp141.599.611 & Rp79.929.289 & Rp71.738.770 \\
\hline 2027 & 7 & Rp150.095.588 & Rp77.022.769 & Rp67.895.621 \\
\hline 2028 & 8 & Rp159.101.323 & Rp74.221.941 & Rp64.258.356 \\
\hline 2029 & 9 & Rp168.647.402 & Rp71.522.962 & Rp60.815.944 \\
\hline 2030 & 10 & Rp178.766.247 & Rp68.922.127 & Rp57.557.947 \\
\hline 2031 & 11 & Rp189.492.221 & Rp66.415.868 & Rp54.474.486 \\
\hline 2032 & 12 & Rp200.861.755 & Rp64.000.745 & Rp51.556.210 \\
\hline 2033 & 13 & Rp212.913.460 & Rp61.673.445 & Rp48.794.270 \\
\hline 2034 & 14 & Rp225.688.268 & Rp59.430.775 & Rp46.180.291 \\
\hline 2035 & 15 & Rp239.229.564 & Rp57.269.655 & Rp43.706.347 \\
\hline 2036 & 16 & Rp253.583.337 & Rp55.187.123 & Rp41.364.935 \\
\hline 2037 & 17 & Rp268.798.338 & Rp53.180.318 & Rp39.148.957 \\
\hline 2038 & 18 & Rp284.926.238 & Rp51.246.488 & Rp37.051.691 \\
\hline 2039 & 19 & Rp302.021.812 & Rp49.382.980 & Rp35.066.779 \\
\hline 2040 & 20 & Rp320.143.121 & Rp47.587.235 & Rp33.188.202 \\
\hline 2041 & 21 & Rp339.351.708 & Rp45.856.790 & Rp31.410.262 \\
\hline 2042 & 22 & Rp359.712.811 & Rp44.189.270 & Rp29.727.570 \\
\hline 2043 & 23 & Rp381.295.579 & Rp42.582.388 & Rp28.135.021 \\
\hline 2044 & 24 & Rp404.173.314 & Rp41.033.937 & Rp26.627.788 \\
\hline 2045 & 25 & Rp428.423.713 & Rp39.541.794 & Rp25.201.299 \\
\hline 2046 & 26 & Rp454.129.136 & Rp38.103.911 & Rp23.851.230 \\
\hline 2047 & 27 & Rp481.376.884 & Rp36.718.314 & Rp22.573.485 \\
\hline 2048 & 28 & Rp510.259.497 & Rp35.383.103 & Rp21.364.191 \\
\hline 2049 & 29 & Rp540.875.067 & Rp34.096.444 & Rp20.219.681 \\
\hline 2050 & 30 & Rp573.327.571 & Rp32.856.574 & Rp19.136.484 \\
\hline \multicolumn{2}{|c|}{ Total } & Rp8.365.262.635 & Rp1.774.587.465 & Rp1.425.446.560 \\
\hline
\end{tabular}

Biaya PENyUsutan PLTMH BANJAR DINAS MEKaR SARI

3. Biaya Air Permukaan Bali

Besarnya biaya air permukaan di provinsi Bali untuk pembangkit listrik tenaga air sebesar Rp.50,- per kWh [18]. Besarnya energi listrik optimal yang dibangkitkan PLTMH sebesar $176 \mathrm{~kW}$, besarnya energi listrik yang dibangkitkan dalam satu tahun sebesar 1.002.144 kWh. Maka besarnya biaya air permukaan yang harus dibayarkan pada pemerintah provinsi Bali setiap tahunnya dapat dilihat pada tabel VI.

Dengan besarnya daya listrik yang dihasilkan sebesar 1.002.144 kWh dengan asumsi konstan, maka didapatkan biaya air permukaan per tahunnya sebesar Rp.50.107.200, dengan besarnya present value Rp.472.356.289 untuk tingkat diskonto 10\% dan Rp.403.622.714 dengan tingkat diskonto $12 \%$.

p-ISSN:1693 - 2951; e-ISSN: 2503-2372 
Setelah dilakukan perhitungan besarnya biaya variabel yang dikeluarkan sepanjang umur ekonomis PLTMH, maka diperoleh besarnya biaya yang dikeluarkan sepanjang umur ekonomis PLTMH yang merupakan parameter Life Cycle Cost dari PLTMH Banjar Dinas Mekar Sari.

TABEL VI

BIAYA AIR PERMUKAAN PLTMH BANJAR DINAS MEKAR SARI

\begin{tabular}{|c|c|c|c|}
\hline \multicolumn{4}{|c|}{ Biaya Air Permukaan } \\
\hline Tahun & Jumlah & $\begin{array}{c}\text { Present Value } \\
\text { harga air } \\
\text { dengan discount rate } \\
10 \%\end{array}$ & $\begin{array}{c}\text { Present Value } \\
\text { harga air } \\
\text { dengan discount rate } \\
12 \%\end{array}$ \\
\hline 2020 & Rp0 & Rp0 & $\mathrm{Rp} 0$ \\
\hline 2021 & Rp50.107.200 & Rp45.552.000 & Rp44.738.571 \\
\hline 2022 & Rp50.107.200 & Rp41.410.909 & Rp39.945.153 \\
\hline 2023 & Rp50.107.200 & Rp37.646.281 & Rp35.665.315 \\
\hline 2024 & Rp50.107.200 & Rp34.223.892 & Rp31.844.031 \\
\hline 2025 & Rp50.107.200 & Rp31.112.629 & Rp28.432.171 \\
\hline 2026 & Rp50.107.200 & Rp28.284.208 & Rp25.385.867 \\
\hline 2027 & Rp50.107.200 & Rp25.712.916 & Rp22.665.953 \\
\hline 2028 & Rp50.107.200 & Rp23.375.379 & Rp20.237.458 \\
\hline 2029 & Rp50.107.200 & Rp21.250.344 & Rp18.069.159 \\
\hline 2030 & Rp50.107.200 & Rp19.318.495 & Rp16.133.177 \\
\hline 2031 & Rp50.107.200 & Rp17.562.268 & Rp14.404.623 \\
\hline 2032 & Rp50.107.200 & Rp15.965.698 & Rp12.861.270 \\
\hline 2033 & Rp50.107.200 & Rp14.514.271 & Rp11.483.277 \\
\hline 2034 & Rp50.107.200 & Rp13.194.792 & Rp10.252.926 \\
\hline 2035 & Rp50.107.200 & Rp11.995.265 & Rp9.154.398 \\
\hline 2036 & Rp50.107.200 & Rp10.904.787 & Rp8.173.570 \\
\hline 2037 & Rp50.107.200 & Rp9.913.442 & Rp7.297.830 \\
\hline 2038 & Rp50.107.200 & Rp9.012.220 & Rp6.515.920 \\
\hline 2039 & Rp50.107.200 & Rp8.192.928 & Rp5.817.785 \\
\hline 2040 & Rp50.107.200 & Rp7.448.116 & Rp5.194.451 \\
\hline 2041 & Rp50.107.200 & Rp6.771.015 & Rp4.637.903 \\
\hline 2042 & Rp50.107.200 & Rp6.155.468 & Rp4.140.985 \\
\hline 2043 & Rp50.107.200 & Rp5.595.880 & Rp3.697.308 \\
\hline 2044 & Rp50.107.200 & Rp5.087.163 & Rp3.301.168 \\
\hline 2045 & Rp50.107.200 & Rp4.624.694 & Rp2.947.471 \\
\hline 2046 & Rp50.107.200 & Rp4.204.267 & Rp2.631.671 \\
\hline 2047 & Rp50.107.200 & Rp3.822.061 & Rp2.349.706 \\
\hline 2048 & Rp50.107.200 & Rp3.474.601 & Rp2.097.952 \\
\hline 2049 & Rp50.107.200 & Rp3.158.728 & Rp1.873.171 \\
\hline 2050 & Rp50.107.200 & Rp2.871.571 & Rp1.672.474 \\
\hline Total & Rp1.503.216.000 & Rp472.356.289 & Rp403.622.714 \\
\hline
\end{tabular}

TABEL VII

LCC PLTMH BANJAR DINAS MEKAR SARI

\begin{tabular}{|c|c|c|c|c|}
\hline \multicolumn{5}{|c|}{ LCC } \\
\hline No. & Parameter & Biaya Pengeluaran & $\begin{array}{c}\text { PV Cost } \\
\text { Discount Rate } 10 \%\end{array}$ & $\begin{array}{c}\text { PV Cost } \\
\text { Discount Rate 12\% }\end{array}$ \\
\hline 1 & Investasi & 2.060 .258 .262 & 2.060 .258 .262 & 2.060 .258 .262 \\
\hline 2 & Biaya O\&M & 6.515 .211 .254 & 1.382 .121 .845 & 1.110 .196 .521 \\
\hline 3 & Biaya Penyusutan & 5.429 .342 .712 & 1.151.768.204 & 925.163 .767 \\
\hline 4 & Biaya Air & 2.173 .356 .000 & 682.934 .704 & 583.559 .414 \\
\hline & Total & 16.178.168.228 & 5.277 .083 .015 & 4.679.177.964 \\
\hline
\end{tabular}

Besarnya biaya pengeluaran sepanjang umur ekonomis PLTMH yaitu Rp.5.277.083.015 dengan tingkat diskonto 10\% dan Rp.4.679.177.964 dengan tingkat diskonto 12\%

\section{B. Proyeksi Pendapatan}

Untuk menghitung proyeksi pendapatan diperlukan besarnya harga jual listrik ke PLN. Menghitung besarnya maksimal penjualan listrik ke PLN dengan menentukan besarnya BPP provinsi Bali yang dikalikan dengan faktor pengali 85\%.[19] BPP provinsi Bali tahun 2019 sebesar Rp.1221 dengan dikalikan faktor 85\% maka harga jual listrik ke PLN maksimal sebesar Rp.1037,85 maka proyeksi pendapatan dengan besarnya energi listrik yang dijual ke PLN sebesar 1.002.144 kWh yaitu.

TABEL VIII

PRoyeKsi Pendapatan PLTMH Banjar DINAS MEKar SARI

\begin{tabular}{|c|c|c|c|}
\hline \multicolumn{4}{|c|}{ Pendapatan } \\
\hline Tahun & Jumlah & $\begin{array}{c}\text { Present Value } \\
\text { Pendapatan Dengan } \\
\text { Discount Rate 10\% }\end{array}$ & $\begin{array}{c}\text { Present Value } \\
\text { Pendapatan Dengan } \\
\text { Discount Rate } 12 \%\end{array}$ \\
\hline 2020 & $\mathrm{Rp} 0,00$ & $\mathrm{Rp} 0,00$ & Rp0 \\
\hline 2021 & Rp1.040.075.150,40 & Rp945.522.864,00 & Rp928.638.527 \\
\hline 2022 & Rp1.040.075.150,40 & Rp859.566.240,00 & Rp829.141.542 \\
\hline 2023 & Rp1.040.075.150,40 & Rp781.423.854,55 & Rp740.304.948 \\
\hline 2024 & Rp1.040.075.150,40 & Rp710.385.322,31 & Rp660.986.561 \\
\hline 2025 & Rp1.040.075.150,40 & Rp645.804.838,47 & Rp590.166.572 \\
\hline 2026 & Rp1.040.075.150,40 & Rp587.095.307,70 & Rp526.934.440 \\
\hline 2027 & Rp1.040.075.150,40 & Rp533.723.007,00 & Rp470.477.178 \\
\hline 2028 & Rp1.040.075.150,40 & Rp485.202.733,63 & Rp420.068.909 \\
\hline 2029 & Rp1.040.075.150,40 & Rp441.093.394,21 & Rp375.061.526 \\
\hline 2030 & Rp1.040.075.150,40 & Rp400.993.994,74 & Rp334.876.362 \\
\hline 2031 & Rp1.040.075.150,40 & Rp364.539.995,22 & Rp298.996.752 \\
\hline 2032 & Rp1.040.075.150,40 & Rp331.399.995,65 & Rp266.961.386 \\
\hline 2033 & Rp1.040.075.150,40 & Rp301.272.723,32 & Rp238.358.380 \\
\hline 2034 & Rp1.040.075.150,40 & Rp273.884.293,93 & Rp212.819.982 \\
\hline 2035 & Rp1.040.075.150,40 & Rp248.985.721,75 & Rp190.017.841 \\
\hline 2036 & Rp1.040.075.150,40 & Rp226.350.656,14 & Rp169.658.787 \\
\hline 2037 & Rp1.040.075.150,40 & Rp205.773.323,76 & Rp151.481.060 \\
\hline 2038 & Rp1.040.075.150,40 & Rp187.066.657,97 & Rp135.250.946 \\
\hline 2039 & Rp1.040.075.150,40 & Rp170.060.598,15 & Rp120.759.773 \\
\hline 2040 & Rp1.040.075.150,40 & Rp154.600.543,77 & Rp107.821.226 \\
\hline 2041 & Rp1.040.075.150,40 & Rp140.545.948,88 & Rp96.268.952 \\
\hline 2042 & Rp1.040.075.150,40 & Rp127.769.044,44 & Rp85.954.421 \\
\hline 2043 & Rp1.040.075.150,40 & Rp116.153.676,76 & Rp76.745.019 \\
\hline 2044 & Rp1.040.075.150,40 & Rp105.594.251,60 & Rp68.522.339 \\
\hline 2045 & Rp1.040.075.150,40 & Rp95.994.774,19 & Rp61.180.659 \\
\hline 2046 & Rp1.040.075.150,40 & Rp87.267.976,53 & Rp54.625.589 \\
\hline 2047 & Rp1.040.075.150,40 & Rp79.334.524,12 & Rp48.772.847 \\
\hline 2048 & Rp1.040.075.150,40 & Rp72.122.294,65 & Rp43.547.185 \\
\hline 2049 & Rp1.040.075.150,40 & Rp65.565.722,41 & Rp38.881.415 \\
\hline 2050 & Rp1.040.075.150,40 & Rp59.605.202,19 & Rp34.715.549 \\
\hline
\end{tabular}

\section{Cash Flow}

Setelah diperoleh besarnya proyeksi pendapatan sepanjang umur ekonomis PLTMH yaitu 30 tahun. Maka selanjutnya dilakukan analisis parameter cash flow dengan menggunakan data LCC dan proyeksi pendapatan sebagai berikut.

Dilihat pada tabel diatas dari analisis cash flow, keuntungan baru diperoleh setelah melalui tahun ke-3 sebelum discount dan tahun ke-5 setelah discount dari umur ekonomis PLTMH.

\section{Analisis Parameter Ekonomi}

Analisis ekonomi PLTMH dengan memperhatikan parameter ekonomi finansial diantaranya BCR, NPV, IRR, PP, dan BEP. Perhitungan parameter ekonomi dilakukan dengan persamaan (2), (3), (4), (5), dan (6). 
$10 \%$ dan $12 \%$ bernilai positif maka proyek dikatakan layak dari parameter NPV.

Besarnya IRR yaitu 13\% di tingkat diskonto 10\% dan 11\%

TABEL IX

CASH FLOW PLTMH BANJAR DINAS MEKar SARI

\begin{tabular}{|c|c|c|c|}
\hline \multicolumn{4}{|c|}{ Cash Flow } \\
\hline \multicolumn{2}{|r|}{ No Discount } & Discount Rate $10 \%$ & Discount Rate $12 \%$ \\
\hline Tahun & Cash Flow & Cash Flow & Cash Flow \\
\hline 2020 & -Rp3.174.344.000 & -Rp3.174.344.000 & -Rp3.174.344.000 \\
\hline 2021 & -Rp2.353.674.396 & -Rp2.428.280.724 & -Rp2.441.603.282 \\
\hline 2022 & -Rp1.543.162.693 & -Rp1.758.436.341 & -Rp1.795.468.315 \\
\hline 2023 & -Rp743.418.365 & -Rp1.157.576.591 & -Rp1.226.226.099 \\
\hline 2024 & Rp44.912.545 & -Rp619.135.971 & -Rp725.227.554 \\
\hline 2025 & Rp776.232.688 & -Rp137.156.543 & -Rp284.772.280 \\
\hline 2026 & Rp763.408.573 & Rp293.767.694 & Rp101.994.261 \\
\hline 2027 & Rp749.815.010 & Rp384.773.660 & Rp339.178.231 \\
\hline 2028 & Rp735.405.834 & Rp343.072.249 & Rp297.018.082 \\
\hline 2029 & Rp720.132.107 & Rp305.406.311 & Rp259.686.857 \\
\hline 2030 & Rp703.941.956 & Rp271.400.097 & Rp226.650.470 \\
\hline 2031 & Rp686.780.396 & Rp240.712.339 & Rp197.432.953 \\
\hline 2032 & Rp668.589.143 & Rp213.033.105 & Rp171.610.180 \\
\hline 2033 & Rp649.306.415 & Rp188.080.940 & Rp148.804.272 \\
\hline 2034 & Rp628.866.722 & Rp165.600.263 & Rp128.678.591 \\
\hline 2035 & Rp607.200.649 & Rp145.359.008 & Rp110.933.288 \\
\hline 2036 & Rp584.234.611 & Rp127.146.473 & Rp95.301.321 \\
\hline 2037 & Rp559.890.610 & Rp110.771.372 & Rp81.544.899 \\
\hline 2038 & Rp534.085.970 & Rp96.060.056 & Rp69.452.321 \\
\hline 2039 & Rp506.733.051 & Rp82.854.903 & Rp58.835.141 \\
\hline 2040 & Rp477.738.957 & Rp71.012.852 & Rp49.525.652 \\
\hline 2041 & Rp447.005.217 & Rp60.404.070 & Rp41.374.629 \\
\hline 2042 & Rp414.427.453 & Rp50.910.744 & Rp34.249.325 \\
\hline 2043 & Rp379.895.024 & Rp42.425.976 & Rp28.031.677 \\
\hline 2044 & Rp343.290.648 & Rp34.852.788 & Rp22.616.710 \\
\hline 2045 & Rp304.490.010 & Rp28.103.209 & Rp17.911.109 \\
\hline 2046 & Rp263.361.333 & Rp22.097.452 & Rp13.831.950 \\
\hline 2047 & Rp219.764.936 & Rp16.763.160 & Rp10.305.565 \\
\hline 2048 & Rp173.552.756 & Rp12.034.729 & Rp7.266.527 \\
\hline 2049 & Rp124.567.844 & Rp7.852.683 & Rp4.656.754 \\
\hline 2050 & Rp72.643.838 & Rp4.163.113 & Rp2.424.700 \\
\hline 10tal & .274.295 & 3.318 .659 .249 & 2.519. \\
\hline
\end{tabular}

Hasil analisis ditampilkan dalam tabel berikut.

TABEL X

ANALISIS EKONOMI PLTMH BANJAR DINAS MEKAR SARI

\begin{tabular}{|c|c|c|}
\hline \multicolumn{3}{|c|}{ Hasil Analisa Ekonomi } \\
\hline & DR $10 \%$ & DR $12 \%$ \\
\hline Parameter & & 0,79 \\
\hline BCR & 1,05 & Rp2.519.315.466 \\
\hline NPV & Rp3.318.659.249 & $11 \%$ \\
\hline IRR & $13 \%$ & 3784309,90 \\
\hline BEP & \multicolumn{2}{|c|}{30.8361 .211} \\
\hline LCC & Rp6.486.040.233 & Rp5.858.683.2 \\
\hline PP & 5,3 & 5,3 \\
\hline
\end{tabular}

Dilihat dari tabel di atas diperoleh besarnya nilai parameter ekonomi. Nilai parameter ekonomi menjadi tolak ukur kelayakan PLTMH.

Besarnya NPV yang diperoleh sebesar Rp.3.318.659.249 di tingkat diskonto 10\% dan Rp.2.519.315.466 di tingkat diskonto 12\%. Besarnya nilai NPV dengan tingkat diskonto di tingkat diskonto 12\%. Besarnya IRR digunakan untuk mengetahui besarnya persentase pengembalian yang

TABEL XI

Pembagian SHU PLTMH Banjar DInas Mekar Sari Bagi Hasil Kelompok Masyarakat

\begin{tabular}{|c|c|c|}
\hline \multicolumn{3}{|c|}{ Bagi Hasil Kelompok Masyarakat } \\
\hline \multirow{3}{*}{ Tahun } & Keuntungan PLTMH DR 10\% & Keuntungan PLTMH DR 12\% \\
\cline { 2 - 3 } & $\begin{array}{c}\text { Pembagian SHU } \\
\text { (22 Anggota) }\end{array}$ & $\begin{array}{c}\text { Pembagian SHU } \\
\text { (22 Anggota) }\end{array}$ \\
\hline 2020 & - & - \\
\hline 2021 & - & - \\
\hline 2022 & - & - \\
\hline 2023 & - & - \\
\hline 2024 & - & - \\
\hline 2025 & - & - \\
\hline 2026 & Rp13.353.077 & Rp4.636.103 \\
\hline 2027 & Rp17.489.712 & Rp15.417.192 \\
\hline 2028 & Rp15.594.193 & Rp13.500.822 \\
\hline 2029 & Rp13.882.105 & Rp11.803.948 \\
\hline 2030 & Rp12.336.368 & Rp10.302.294 \\
\hline 2031 & Rp10.941.470 & Rp8.974.225 \\
\hline 2032 & Rp9.683.323 & Rp7.800.463 \\
\hline 2033 & Rp8.549.134 & Rp6.763.831 \\
\hline 2034 & Rp7.527.285 & Rp5.849.027 \\
\hline 2035 & Rp6.607.228 & Rp5.042.422 \\
\hline 2036 & Rp5.779.385 & Rp4.331.878 \\
\hline 2037 & Rp5.035.062 & Rp3.706.586 \\
\hline 2038 & Rp4.366.366 & Rp3.156.924 \\
\hline 2039 & Rp3.766.132 & Rp2.674.325 \\
\hline 2040 & Rp3.227.857 & Rp2.251.166 \\
\hline 2041 & Rp2.745.640 & Rp1.880.665 \\
\hline 2042 & Rp2.314.125 & Rp1.556.788 \\
\hline 2043 & Rp1.928.453 & Rp1.274.167 \\
\hline 2044 & Rp1.584.218 & Rp1.028.032 \\
\hline 2045 & Rp1.277.419 & Rp814.141 \\
\hline 2046 & Rp1.004.430 & Rp628.725 \\
\hline 2047 & Rp761.962 & Rp330.435 \\
\hline 2048 & Rp547.033 & Rp211.671 \\
\hline 2049 & Rp356.940 & Rp110.214 \\
\hline 2050 & Rp189.232 & \\
\hline & & \\
\hline
\end{tabular}

didapatkan dari proyek PLTMH ini. Dan syarat IRR dikatakan layak harus melebihi Expected Future Annual Return Indonesia sebesar $11,4 \%$. Karena nilai IRR sudah melebihi $11,4 \%$ maka dari parameter IRR proyek PLTMH dikatakan layak.

Benefit to Cost Ratio (BCR) merupakan perbandingan keuntungan yang didapat dengan besarnya initial cost. Besarnya nilai BCR yaitu 1,05 di tingkat diskonto 10\% dan 0,79 di tingkat diskonto 12\%. Besarnya BCR mendekati angka 1 , maka parameter BCR layak.

Parameter BEP merupakan keadaan saat arus kas berada pada titik Rp.0 dimana keuntungan sudah melebihi atau sama dengan besarnya initial cost. BEP unit menghitung banyaknya penjualan unit yang diperlukan untuk memenuhi parameter BEP. Dalam analisa didapatkan besarnya BEP unit yaitu 3.784.309,9 kWh. Jadi besarnya energi yang harus dijual untuk mencapai BEP yaitu 3.784.309,9 kWh.

Richard Antony Suatan : Kajian Ekonomi Untuk Perencanaan... 
Parameter payback period merupakan parameter untuk menentukan jangka waktu balik modal dari suatu proyek. Untuk perancangan PLTMH ini besarnya jangka waktu pengembalian modal yaitu 5 tahun 3 bulan. Karena pengembalian modal dari PLTMH ini tidak melebihi umur ekonomisnya, maka dari parameter payback period proyek PLTMH layak.

\section{E. Model Pengelolaan}

Sistem pengelolaan yang dianjurkan untuk mengelola PLTMH yaitu model koperasi produksi dengan modal bersama secara swadaya dari masyarakat yang berjumlah 22 KK dengan pembagian modal sama rata.

Dengan asumsi modal usaha berasal dari masyarakat, maka besarnya keuntungan yang diperoleh dari PLTMH dibagikan secara merata sejumlah anggota kelompok masyarakat yaitu 22 KK. Sehingga keuntungan bagi masyarakat di peroleh dengan cari pembagian sisa hasil usaha (SHU) yang dibagikan merata untuk masyarakat.

Dapat dilihat pada tabel di atas pada tahun pertama belum bisa dilakukan bagi hasil karena nilai keuntungan PLTMH belum ada, atau masih berada dalam keadaan rugi. Pembagian sisa hasil usaha baru bisa dilakukan pada tahun ke-6 saat tidak ada utang dari investasi.

\section{KESIMPULAN}

Kesimpulan yang dapat diambil dari hasil analisis perencanaan PLTMH Banjar Dinas Mekar Sari yaitu besarnya biaya investasi untuk membangun PLTMH di Banjar Dinas Mekar Sari, Kecamatan Sukasada, Kabupaten Buleleng, Bali sebesar Rp3.174.344.000 dan setelah dilakukan analisis dengan parameter ekonomi diperoleh besarnya parameter $B C R$ 1,05 dan 0,79 serta nilai NPV sebesar Rp.3.320.076.318 dan Rp.2.520.526.334 bernilai positif saat tingkat diskonto $10 \%$ dan $12 \%$, serta besarnya nilai IRR $13 \%$ dan $11 \%$ melebihi tingkat Expected Annual Rate of Return Indonesia yang sebesar $11,4 \%$. Serta besarnya $B E P$ unit yang harus dijual untuk mencapai titik cash flow bernilai Rp.0 sebesar 3.783.633,3 kWh, dan besarnya payback period pada proyek ini yaitu 5 tahun 3 bulan.

Dilihat dari parameter ekonomi yang ada, perencanaan PLTMH di Banjar Dinas Mekar Sari layak untuk dijalankan.

\section{REFERENSI}

[1] Keputusan Menteri Energi dan Sumber Daya Mineral No. 39 K/20/MEM/2019. Tentang Pengesahan Rencana Usaha Penyediaan Tenaga Listrik PT Perusahaan Listrik Negara (Persero) Tahun 2019 Sampai Dengan Tahun 2028.

[2] Kementrian Energi Dan Sumber Daya Mineral. 2016. Jurnal Energi Media Komunikasi Kementerian Energi dan Sumber Daya Mineral.

[3] Balitbang ESDM. 2017. Ketenagalistrikan dan EBTIKE, Mikrohido. Jakarta : Kementrian ESDM

[4] Dutch-German Partnership Energising Development Mini Hydro Power Project. Panduan Singkat Pengembangan Pembangkit Listrik Tenaga Mikrohidro (PLTMH). Jakarta : Kementrian ESDM

[5] Coaction. 2019. https://coaction.id/air-sebagai-sumber-energiterbarukan/. Jakarta : Collaborate Advocate Breaking Barriers.

[6] Balai Wilayah Sungai Bali-Penida. Data Tukad Banyumala, Tukad Pasut. Bali : Kementrian PUPR.

[7] Widiana, Nengah. 2020. Perancangan Penstok (Pipa Peesat) Untuk Pembangkit Listrik Tenaga Mikrohidro (PLTMH) Di Banjar Dinas Mekarsari, Desa Panji, Kecamatan Sukasada, Kabupaten Buleleng. Bali : Universitas Udayana
[8] IMIDAP. 2009. PEDOMAN STUDI KELAYAKAN EKONOMI / FINANSIAL. Jakarta : Kementrian ESDM.

[9] Barringer \& Weber. 1996. Life Cycle Cost Tutorial. Fifth International Conference on Process Plant Reliability.

[10] Ulfathu, Vivin. 2016. Analisis Break Even Point Sebagai Alat Perencanaan Penjualan Pada Tingkat Laba Yang Diharapkan (Studi Kasus pada Perhutani Plywood Industri Kediri Tahun 2013-2014). Jurnal Administrasi Bisnis (JAB), Vol. 35 No. 1 hal. 196-206.

[11] Focus, Guru. 2020. Buffett Indicator: Indonesia Stock Market Valuations and Expected Future Returns.

[12] Abdul Choliq. (2004:59). "Pengertian payback period" diakses dari https://rumus.co.id/rumus-paybackperiod/\#Cara_Menghitung_Payback_Period

[13] Laksana, Ari. 2020. Redesain Turbin 175 kW Untuk Pembangkit Listrik Tenaga Mikrrohidro PLTMH Desa Mekar Sari Buleleng Bali. Bali : Univesrsitas Udayana

[14] Aprilyanto, Eka. 2020. Perencanaan Sistem Kelistrikan Pembangkit Listrik Tenaga Mikrohidro Di Banjar Dinas Mekar Sari, Desa Panji Kecamatan Sukasada, Kabupaten Buleleng. Bali : Universitas Udayana.

[15] PERMEN ESDM No. 4 th. 2020 Pasal 7 ayat 4 butir a. nomor 1 . Tentang Perubahan Kedua atas Peraturan Menteri Energi dan Sumber Daya Mineral Nomor 50 tahun 2017 tentang Pemanfaatan Sumber Energi Terbarukan Untuk Penyediaan Tenaga Listrik.

[16] Suatan, Richard. 2020. Kajian Ekonomi Perencanaan Pembangkit Listrik Tenaga Mikrohidro (PLTMH) di Banjar Dinas Mekar Sari Desa Panji Kecamatan Sukasada Kabupaten Buleleng. Bali: Universitas Udayana.

[17] IRENA. 2012. Renewable Energy Technologies: Cost Analysis Series. Irena Working Paper.

[18] PERGUB BALI No. 6 Tahun 2009 Pasal 1 Ayat 2 butir b. Tentang Harga Dasar Air Pengenaan Pajak Pengambilan dan Pemanfaatan Air Bawah Tanah Dan Air Permukaan. Bali : PemProv. Bali.

[19] PERMEN ESDM No. 12 th. 2017. Tentang Pemanfaatan Sumber Energi Terbarukan Untuk Penyediaan Tenaga Listrik.

[20] Moonti, Usman. 2016. Bahan Ajar Mata Kuliah Dasar - Dasar Koperasi.

[21] PERGUB BALI No. 45 th. 2019. Tentang Bali Energi Bersih. Bali : Pemerintahan Provinsi Bali. 